\title{
Long Lease Real Estate - A Revised Role for Real Estate in Pension Fund Portfolios
}

\author{
Nick Mansley and Zilong Wang ${ }^{\mathrm{a}}$ \\ a Department of Land Economy, University of Cambridge, Cambridge, CB3 9EP, UK
}

\begin{abstract}
Purpose: Long lease real estate funds (over $115 \mathrm{bn}$ in Q3 2020) have emerged as an increasingly important part of UK pension fund real estate portfolios. This paper explores the reasons for their dramatic growth, their characteristics and performance.
\end{abstract}

Design: This study uses data for the period 2004-2020 collected directly from fund managers and from $A R E F / M S C l$ and empirical analysis to explore their characteristics and performance.

Findings: Pension fund de-risking and regulatory guidance have supported the dramatic growth of long lease real estate funds. Long lease real estate funds have delivered strong risk-adjusted returns relative to both balanced property funds (with shorter lease terms) and the wider property market. This relative performance has been particularly strong when wider property market performance has been weak. Long lease funds have objectives aligned with liability matching and their performance suggests they are lower risk (more bond-like) investments. In addition, our analysis highlights they are far less responsive to the wider property market than balanced funds. However, they are not significantly different from balanced property funds in terms of their short-term relationship with gilt yield movements.

Practical Implications: For pension funds and other investors the paper highlights that long lease real estate funds offer a different exposure than balanced property funds. Long lease funds have objectives more closely aligned to the overall objectives for pension fund investment but are not significantly more reliable than balanced property funds in the short-term as a liability hedge. For real estate fund managers, occupiers, developers and others active in the real estate market, the paper highlights why these funds have been (and are likely to remain) attractive to investors leading to substantial demand for long lease real estate investments.

Originality: This is the first study to review this increasingly important part of the UK real estate fund universe.

\section{Introduction}

Real estate's role in pension fund portfolios traditionally has partly reflected potential diversification benefits and partly that it offers something between the returns and risk of bonds and equities. One of the key issues facing defined benefit pension schemes has been how to allocate assets to de-risk their portfolios as they mature in an environment in which the prospective returns from bonds have fallen sharply. The emergence of long lease real estate funds in the UK (along with directly-held real estate investments focussed on long lease/"secure income" real estate) suggests that part of the response to these pressures has been for pension funds to move their real estate exposure into more "bond-like" real estate assets. The UK has been at the forefront of the growth of long lease real estate exposure and benefits from the availability of data.

This raises the questions, which this paper seeks to address: 
- Why have long lease real estate funds grown so rapidly?

- What are the performance and risk characteristics of long lease real estate funds?

- To what extent do long lease real estate funds behave like direct real estate or bonds and how does this compare balanced property funds?

This is the first paper that analyses the return and risk characteristics of long lease real estate. It also sets out the factors that have driven the growth of long lease real estate. Long lease property funds have grown to $\mathrm{c} f 15 \mathrm{bn}^{1}$ and now represent a substantial proportion of the institutional open-ended UK real estate fund investment universe. The rapid growth of these funds has reflected a combination of the increasing maturity of pension funds, the regulatory environment for pension funds and their risk and performance characteristics. We identify that long lease property funds have fundamentally different performance objectives and have performed differently from commercial property. Long lease property portfolios have out-performed expectations given their real estate sector allocation. The outperformance primarily arises during crisis periods including the Global Financial Crisis (GFC), the aftermath of the EU referendum, and the Covid-19 outbreak. Long lease funds' return is less sensitive to the real estate market than balanced funds. However, the relationship between long lease real estate funds and short-term gilt yield movements is not significantly different from balanced property funds suggesting no significant difference in their short-term liability hedging characteristics.

$\mathrm{MSCl} / \mathrm{AREF}$ defines Long lease (long income) real estate funds as "Funds with a non-property specific performance objective to out-perform long-term bonds or gilts. Funds typically maintain average unexpired lease lengths of over 15 years. Lease length, tenant quality and minimum leverage, in addition to a diversified portfolio, aims to maintain consistent long term income." The long lease real estate funds used for this study share a focus on long income with over $50 \%$ of income from leases with over 20 years remaining, have no debt, no or negligible vacancy and aim to out-perform bonds or a real return benchmark.

Long lease real estate funds invest across all segments of the real estate market with exposure to retail, offices and industrial real estate but have a markedly higher exposure to the "other" sector than balanced fund and market indices. Section 2 sets out the context for this research, one in which bond yields have fallen and allocations within pension funds have moved from growth assets to those more focussed on liability matching. Over the past two decades, long lease real estate funds have emerged as a substantial proportion of the UK institutional real estate fund investment universe whilst the security of income from real estate more generally has declined. Section 3 considers the literature on the role of real estate in a mixed-asset portfolio and the performance of real estate funds. Section 4 discusses the data and the characteristics of the long lease real estate funds used in this study. Section 5 discusses the theoretical drivers of long lease fund performance and the empirical approach. The empirical analysis is set out in Section 6 followed by a discussion of the key findings and conclusions in Section 7.

\section{Background - The pensions and property context for the rise of the long lease real estate fund}

The UK pension fund universe has changed substantially over the past 15 years as pension funds have closed to new members and closed to new benefit accrual. In 2006, 43\% were open, $44 \%$ were closed to new members and only $13 \%$ were closed to new benefit accrual (or winding up). In 2020,

\footnotetext{
${ }^{1}$ The size of the long lease funds ( $f 15 \mathrm{bn}$ ) is based on the net asset value of the underlying funds that obtained directly from fund manager and AREF/MSCl. The figure is also cross checked with the Association of Real Estate Funds.
} 
only $11 \%$ were open and $46 \%$ were closed to new benefit accrual or winding up (Pension Protection Fund, 2020).

This has led to a substantial decline in the number of active members in UK defined benefit pension schemes from over 3.5m in 2006 to 1.0m in 2020 (PPF Pension Protection Fund, 2020). These closures are partly a reflection of the potential costs for corporates of addressing scheme deficits there is a statutory funding objective and a need for recovery plans to be in place where the statutory funding objective is not met (The Pension Regulator, 2019). The aggregate funding ratio of UK pension schemes declined from 108.8\% in 2007 to $79.6 \%$ in 2009 (equivalent to a net funding position of -f200.6bn). It briefly recovered in 2010 and 2011 but as bond yields fell, the overall net fund deficit reached $£ 244.2 \mathrm{bn}$ in 2015 (Pension Protection Fund, 2020). Consequently, pension schemes have looked to reduce deficits and reduce risk, reducing exposure to equities $(61 \%$ in 2006 to $20 \%$ in 2020) and increasing exposure to bonds (28\% in 2006 to $69 \%$ in 2020) (Pension Protection Fund, 2020).

Over this period, there has been a substantial fall in bond yields. 10 -year gilt yields were $5.5 \%$ in June 2007 but by June 2020 were $0.2 \%$ and index-linked gilt yields showed a similar fall ${ }^{2}$. The fall in bond yields has led to a "hunt for yield" (UBS, 2015) as investors have sought assets with liability matching characteristics but with additional yield. At the same time, The Pensions Regulator (TPR) in the UK has provided specific guidance about what assets are suitable for matching purposes. This specifically highlights the role of long lease property: "Your scheme's matching asset portfolio may comprise only physical (i.e. non-derivative) assets, e.g. fixed or index-linked gilts, corporate bonds, long-lease property and some forms of infrastructure" (The Pension Regulator, 2019).

Furthermore, TPR highlights that it is a legal requirement for scheme assets to be properly diversified and invites schemes to consider diversification in terms of asset classes. The Regulator's explicit recognition of the role of long lease property as a matching asset and the encouragement to diversify from bonds has potentially played an important role in the growth of long lease property funds. Balanced property funds and other more general property assets are not seen by TPR as appropriate for matching purposes.

Whilst the maturing of pension schemes and regulation has been supportive of a greater focus on the security of income, general commercial real estate has seen a reduction in income security. Over the past two decades, the weighted average lease term on new leases has fallen from 12.3 years to under 9 years ${ }^{3}$ (to lease expiry or first break). In addition, the growing use of Company Voluntary Arrangements has raised questions about the income protection provided by leases particularly in the retail sector.

UK real estate performance has been cyclical with substantial falls in real capital values in the 199092 and 2007-9 periods (IPF, 2020). More recently, there has been weakness in overall commercial property market with values falling $10 \%$ in nominal terms over the two years to September 2020. This gives two periods of falling overall real estate values to assess how resilient long lease property funds have been to when overall real estate performance has been weak. There were also more modest falls in real estate values in the aftermath of the Brexit referendum (-2.4\% in Q3 2016) and between Sept 2011 and March 2013 when values fell by $3.4 \%{ }^{4}$.

\footnotetext{
2 Those figures are based on the Yield Curve database from Bank of England.

${ }^{3}$ Source: MSCI Lease Events Review 2019.

${ }^{4}$ Those figures are based on MSCI UK Quarterly Property index.
} 
In this environment, long lease property funds have emerged as a substantial proportion of the fund universe. Figure 1 shows the overall value of long lease property funds over time and expresses this as a share of the value of balanced property funds in the AREF/MSCl database.

$<$ Insert Figure 1 about here $>$

\section{Related literature}

This section considers the literature on pension fund allocations and real estate fund performance drivers and its relevance to our research on long lease real estate fund performance. Firstly, we briefly consider the literature on asset allocation and real estate to highlight the rationale for allocations to real estate, including the relationship with bonds and interest rates. Secondly, we discuss the literature on performance drivers of funds. Many of these studies face issues with the availability of data constraining the time-period or variables that can be analysed or requiring adjustments to the data which may impact the quality and robustness of the results.

A stream of literature examines the role of real estate in a mixed-asset portfolio. These studies have typically employed the classic mean-variance approach and highlight the diversification benefits of including real estate in a mixed-asset portfolio (Kallberg et al., 1996; Andrew and Glenn, 2003, Lekander, 2015). The low correlation of bonds with real estate (and equities and real estate) explains the diversification benefits of real estate. Studies have suggested that the optimal allocation to real estate should be in the $15-25 \%$ range (see, among others, Chun et al., 2004; Hoesli et al., 2004). However, the actual allocation to real estate for most institutional investors is below 10\%. (Defau and De Moor, 2021; Hoesli and Lekander, 2005; Institutional Real Estate, 2018; IPF, 2007; Schroders, 2019, Carlo et al., 2021). This phenomenon has been considered as a puzzle in real estate research. Rehring (2012) pointed out that ignoring transaction costs, return predictability, and marketing period risk in previous studies could yield misleading results for optimal allocation in real estate. Lekander (2015) highlights the composition of the real estate portfolio (and sensitivity to local markets) influences the optimal asset allocation. This is an issue relevant to this research given the potentially lower sensitivity of long lease real estate to market conditions. Rehring (2012), Lee and Stevenson (2006), Pagliari (2017), and Delfim and Hoesli (2019) emphasised the importance of investment horizon in determining the optimal allocation in real estate. More closely related to our research, several studies have investigated the role of real estate in pension plans' portfolio allocation, taking account of the fact that pension fund managers consider the covariance between asset returns and liabilities. Assets that are highly correlated with pension liabilities are considered to have a liability hedging feature. Thus, those assets should have a high portfolio weight. Ciochetti et al. (1999) observed that pension funds have a low level of allocation to real estate. Chun et al. (2000) and Craft (2001) showed that the low level of allocation to real estate is due to the low correlation between real estate and pension liabilities. In other words, real estate has a limited liability hedging feature. If an asset is more sensitive to the interest rate, it should provide a better liability hedging function. The sensitivity of asset values to changes of interest rates is typically defined as duration. Hartzell et al. (1988) claimed that the duration of real estate might not be low and it depends on the lease length. The longer the lease, the longer the duration. Thus, real estate with longer leases might have a better liability hedging function. Chaney and Hoesli (2010) confirmed the positive relationship between lease length and duration. These findings provided a rationale for including long lease real estate in pension fund portfolios. 
Due to the lack of long lease real estate data, the works of Hartzell et al. (1988) and Chaney and Hoesli (2010) are based on simulations. However, due to the recent rapid development of long lease property funds in the UK and the availability of fund performance data, it provides us with the opportunity to analyse the actual risk and return characteristics of long lease property funds. Our research is also closely related to the literature on the drivers of private real estate fund returns and follows the method most widely used in this literature, panel regression. Based on analysis of US private real estate funds, fund size, underlying property market and macroeconomics condition (inflation, GDP growth rate, interest rate changes) are found to be important drivers of fund returns (Tomperi 2010; Arnold et al., 2019). In addition, Arnold et al. (2019) and Farrelly and Stevenson (2016) found that vintage volume has a negative impact on the fund performance. Similar fund performance drivers have been found by analysing European real estate real estate funds. Fuerst and Matysiak (2013) analysed INREV data and found that fund size, investment style, gearing, lagged GDP growth rate, stock market return, and government bond rate are important factors for fund performance. Using a similar dataset, Delfim and Hoesli (2016) found that fund size, investment style, vehicle structure, vintage, gearing and several macroeconomic variables are important factors for fund returns. INREV data includes both open-ended and closed-ended funds and they found that during the global financial crisis, closed-ended funds had greater losses compared to open-ended funds.

In terms of other important drivers of fund returns, Alcock et al. (2013) showed that leverage does not appear to be a reliable long-term strategy to enhance performance based on a sample of private real estate funds across the globe. Another potential driver of fund performance is investment strategy. Based on US private real estate funds from Burgiss, Fisher and Hartzell (2016) showed that there is no performance difference between value-added and opportunistic funds on average. Using Asian private real estate funds from ANREV, Mansley et al. (2020) analysed the performance differences among core, value-added and opportunistic funds. They found no significant difference in returns and systematic risk across funds with different investment strategies but increased specific risk in more opportunistic funds. On a risk-adjusted basis, Bollinger and Palgliari (2019) and Pagliari (2020) found that value-added and opportunistic funds underperform core funds in the US. Focussing on the role of specialisation, based on European private real estate funds from INREV, Fuerst et al. (2021) showed both country specialisation and country-sector specialisation are associated with superior returns while sector specialisation is not.

The above literature on real estate as an asset class can provide diversification benefits to investors and potentially an element of liability hedging for pension funds. Based on simulations, longer lease real estate might be a better liability hedge than balanced real estate funds. However, the return and risk characteristics of long lease real estate and the extent to which it provides liability hedging are under-explored. Given the growth of long lease real estate funds in the UK and the availability of data, it provides the opportunity to investigate the features of long lease real estate and fill this literature gap. This study is also related to the performance of private real estate funds. Previous studies, summarised above, have found that funds size, vintage, gearing, investment style, specialisation and macroeconomic conditions to be important drivers of real estate funds. This study adds another important dimension, analysing the effect of lease structure on fund performance.

\section{Long Lease Real Estate Funds - Data and Characteristics}

This study uses data from AREF/MSCl on funds complemented with additional data collected directly from fund managers to expand the coverage. The data covers the period between 2004 and 2020. 
Table I below describes key characteristics of long lease property funds, balanced property funds universe, MSCI Monthly Property Index (MPI), and 10-year Gilt Total Return Index. MPI data is from $\mathrm{MSCl}$ and 10-year Gilt data is from the Bank of England website. The funds in the sample are tradeable funds, with pricing and returns based on NAV and it is therefore reasonable to compare long lease property funds with both balanced commercial property funds and property market indices as well as potentially with other asset classes. Both long lease property funds and balanced property funds are typically ungeared and hold small cash balances, meaning the fund (NAV) performance broadly reflects their underlying real estate portfolios but with an impact of transaction costs and fund management fees not reflected in the MPI. Amongst long lease property funds there are differences in the focus of the funds with some more focussed on high quality credit and longer leases, but all have performed similarly over the longer term with a standard deviation of five-year returns across funds of only $0.6 \%$. This compares with a comparable figure of $1.2 \%$ for balanced property funds ${ }^{5}$.

Figure 2 shows the annual total return performance of long lease property funds, balanced property funds, direct property, and bonds over time. Balanced property funds performed very similarly to direct property. The returns of long lease property funds are less volatile compared to balanced property funds and direct property. Gilt returns have tended to move in the opposite direction to property returns. The correlations between gilt returns and the three property return series are between -0.175 to -0.205 .

Long lease property funds have out-performed both balanced property funds and the MPI, despite fund costs (excluded from the MPI measure). Long lease property funds have also been more stable with a standard deviation of annual returns of $7.1 \%$ compared to over $12 \%$ for balanced property funds and the MPI. This volatility is closer to the standard deviation of gilts return (5.2\%). Historically, it appears that long lease property has been both higher returning and lower risk than general commercial property. The returns for long lease property funds, balanced funds and the index all have a negative skew and relatively large tails. The maximum drawdown, in terms of fall in the total return index is under $20 \%$ for long lease property compared to nearly $40 \%$ for both balanced funds and the index. However, it is markedly higher than for gilts (7.1\%) over this period. In terms of risk-adjusted return, long lease property funds have a higher Sharpe ratio than balanced funds or the index but it is lower than gilts over this period on an annual basis.

Long lease property funds have objectives to out-perform gilts ( $42 \%$ by value), provide a real return $(43 \%)$ or a hybrid, a mix of inflation and fixed uplifts, $(15 \%)$. This is noticeably different from balanced property funds, which typically seek to provide a diversified commercial property exposure, and, which typically have performance objectives focussed on the peer group e.g. the balanced fund index or a more general property index benchmark like the MPI.

These differences in objectives are reflected in the unexpired lease terms. For longer lease property funds, over $50 \%$ of the income is from leases of over 20 years with only $1 \%$ from leases of less than 10 years. This compares with balanced funds with over $57 \%$ of income from leases of less than 10 years unexpired and less than $5 \%$ of income on leases of over 20 years. To find longer lease length real estate, fund managers have invested heavily in sectors outside traditional commercial property the "other" sector - including residential, student accommodation/buildings leased to universities

\footnotetext{
${ }^{5}$ Figures are based on author's calculations. The data for calculations are obtained directly from fund manager and AREF/MSCI.
} 
and hotels. The "other sector" accounts for $46 \%$ of NAV for long lease property funds - this compares to a figure of under $11 \%$ for balanced property funds and $10 \%$ in the $\mathrm{MPI}^{6}$.

$<$ Insert Table I about here $>$

$<$ Insert Figure 2 about here $>$

\section{Performance drivers of long lease real estate and empirical approach}

\subsection{The drivers of long lease value}

For any property, the value (V) can be broken down between:

(i) the discounted value of the contracted guaranteed income stream (adjusting for any expected loss through defaults) during the term of the lease (VL);

(ii) the discounted value of expected income from rental growth beyond any growth specified in the lease contract during the term of the lease (VRG); and

(iii) the discounted expected value at the end of the lease term, the residual value (VRES).

$$
V=V L+V R G+V R E S
$$

For long lease property, the expectation is that the cash flow is primarily determined through the terms of the lease contract (fixed, fixed uplifts or inflation-linked uplifts) and hence VRG is negligible. VRES will be dependent on expectations of property market fundamentals at the end of the lease and the discount rate. However, VRES is expected to form a relatively small proportion of the overall value for long lease property given that this is discounted over a long period and given the substantial proportion of overall value in the discounted value of the contracted income stream.

Given the certainty of the contracted guaranteed income stream, it is expected that the primary driver of value changes for $V L$ is the discount rate applied to that income. For Government and quasi-Government tenants with negligible default risk, this is expected to reflect a margin over the equivalent bonds to reflect the illiquidity of real estate (with a small premium for default risk for corporates). The value of this element of the overall real estate value should move closely with the bond market. For inflation-linked income streams the value will be affected both by the discount rate and expected inflation. Hence, we have a simple model below:

$$
V L L_{\text {HQ }}=f(\text { Gilts })
$$

The value of very long lease highest credit quality property ( $V L L_{\mathrm{HO}}$ ) is a function of the yield to maturity of Government bonds (Gilts). The nominal yield to maturity is determined by both the real interest rate and expected inflation.

For lower credit quality tenants, whilst the expected income is still largely fixed for a long lease property there is more uncertainty about the income stream reflecting both the credit quality of the tenant and the extent of protection from the property. If we assume the expected value at the end

\footnotetext{
${ }^{6}$ All the figures in this paragraph are based on author's calculations. The data for calculations are obtained directly from fund manager and AREF/MSCI.
} 
of the lease term is related to property market values today, we have a model for lower credit quality or property with less long lease length:

$$
V L L_{L Q}=f(\text { Gilts, Credit Spreads, Property market })
$$

The value of low credit quality property (VLLL) or property with less long lease length is a function of the gilt yield (Gilts), credit spreads and general property market values (Property market). If credit spreads move in line with the wider property market or the protection from the property is the key driver of values for lower credit quality long lease property then the credit spread element may be insignificant and this may simplify to:

$$
V L L_{L Q}=f(G i l t s, \text { Property market) }
$$

Thus, in a generalised form, with these assumptions the value of long lease property is a function of the gilt yield and the property market:

$$
V L L=f(G i l t s, \text { Property market) }
$$

The returns of long lease property are expected to primarily be a function of changes of gilt yield and property market total return.

\subsection{Shift-share analysis}

As outlined in section 4 above, long lease property funds have a very different sectoral structure from balanced property funds. It could be that the performance differences are simply a function of this difference in sector structures - in which case long lease property funds are acting like property but reflecting their sector structure. The literature highlights the importance of market influences. To explore this we use a shift-share approach to identify the extent to which national market movements and sector allocation drive performance. Since we have the sector allocation information for each fund, by using $\mathrm{MSCl}$ index for various sectors as the proxy for sector market movement, we are able to construct the expected return, which is the weighted market return (WMR):

$$
W M R_{i t}=\sum\left(M_{S, t} * w_{S, I, t}\right)
$$

Where $M_{S, t}$ is the market return for sector $\mathrm{S}$ in period $\mathrm{t}$, and $w_{\mathrm{S}, I, t}$ is the weight in sector $\mathrm{S}$ in fund type I in year $\mathrm{t}$.

The differential performance is the actual return less the expected return given the market returns by sector and sector weights. This differential performance captures the effect of all the other factors beyond market performance and sector structure. These other factors will include fund fees, transaction costs and stock selection, including the characteristics of the assets within each sector, including lease structure.

\subsection{Regression analysis}

The underlying assets of long lease property funds and balanced property funds differ in terms of lease length. Hence, analysing the difference between these two types of funds allows us to understand the return and risk characteristics of long lease real estate compared to shorter lease real estate. The literature (see, among others, Delfim and Hoesli, 2016; Fuerst et al., 2021; Mansley et al., 2020) typically uses regression analysis to analyse the drivers of performance of real estate funds. Thus, we use the following regression model to examine the difference in performance between long lease funds and balanced funds: 
where Total Return is the total return of the fund, LongLease is a dummy variable that takes a value of 1 if the fund is a long lease fund, otherwise 0 . $X$ includes a set of variables that capture the fund characteristics, real estate market conditions, and macroeconomics conditions. Size of the fund has been found to be an important driver of return as mentioned in the literature review section.

Following Delfim and Hoesli (2016), we include changes of the yield of 10-year government bonds to capture the impact of bond yield movements. Following Fuerst and Matysiak (2013), we include GDP growth rate to capture the macroeconomic conditions. In addition, we control the underlying real estate market performance by including the real estate market return proxied by the total return of $\mathrm{MSCl}$ all property index. All the variable definitions are listed in the Appendix. Following Mansley et al. (2020) and Fuerst et al. (2021), we use ordinary least squares (OLS) regression to estimate the model. Alternative estimation method results and discussion are presented in the robustness check section (Section 6.3). All regressions are estimated with heteroskedasticity-robust standard error.

\section{Empirical Analysis}

\subsection{Shift-share analysis}

To explore whether differences in fund structures explain the relatively strong performance of long lease funds an expected return is calculated using the sector exposures of long lease property and the index returns by sector. This analysis indicates that sector structure has had an insignificant impact on performance overall. It did help reduce the negative impact of the global financial crisis (GFC) when the sector contribution was positive $(+1.1 \%$ in Q4 $2008,+0.8 \%$ and $+0.6 \%$ in Q1 and Q2 2009 respectively).

The differential performance (that element not explained by market performance and sector structures) is illustrated in Figure 2. Given the impact of transaction costs ${ }^{7}$ and fund expenses, which will have pulled back performance, it is evident that overall that the long lease property portfolios have out-performed what would have been expected given their sector structure. Positive differential performance was particularly noticeable during the GFC but has also been evident in the aftermath of the EU referendum and more recently with the early impact of Covid-19. Given sector mix is not explaining real estate performance, it appears there is something else driving these performance differences, potentially the difference in lease length and the associated sensitivity to real estate and bond market influences.

$<$ Insert Figure 3 about here>

\subsection{Regression Estimation}

To mitigate the issue with valuation smoothing, we use annual data for the regression analysis ${ }^{8}$. Table II shows the regression results. Column (1) presents the benchmark regression across all funds.

\footnotetext{
${ }^{7}$ Long lease property funds have grown dramatically over this period and the vast majority of this growth has come from real estate purchases with the associated acquisition costs (c7\%) and this will have adversely affected performance relative to the index.

${ }^{8} \mathrm{~A}$ large part of any smoothing will have been unwound over a year. Alternatively, we could de-smooth the series, however, fund by fund de-smoothing is subject to substantial estimation error and would shorten the time period for the analysis. The annual data is calculated based on Sept-Sept.
} 
The coefficient of $\mathrm{MSCl}$ is 1.000 and significant at $1 \%$ level, this indicates that for every 100 basis points change in the real estate market return, fund returns change by 100 basis points. The coefficient of Yield1OY is negative and significant, this indicates that fund return is negatively associated with the changes of the gilt yield. The coefficient of LongLease is positive and significant, indicating that long lease funds out-performed balanced funds on average. Since macroeconomic conditions take time to affect the property market and fund performance, we also include the lagged GDP growth rate (LGDP_growth) and the coefficient is positively significant, this indicates that fund return is positively correlated with GDP growth rate.

Column (2) analyses the differences in sensitivity of returns to real estate and bond markets between long lease funds and balanced funds. The interaction term between $\mathrm{MSCl}$ and LongLease (MSCI*LongLease) is negative and significant, this indicates that long lease fund return is less sensitive to the real estate market compared to balanced fund. The interaction term between Yield10Y and LongLease (Yield10Y*LongLease) is insignificant and the coefficient of Yield1OY remain negatively significant, this indicates that returns of both types of funds are negatively associated with the changes of the gilt yield and the sensitivities of fund returns to gilt yield changes are the same between the two types of funds.

Columns (3) analyses the differences in performance during the crisis periods between long lease funds and balanced funds. Crisis is a dummy variable that takes a value of 1 if the year is 2008,2009, 2016 or 2020, otherwise 0 . Those four years cover the GFC, EU referendum, and early Covid-19 periods. Since those periods are associated with poor performance in the real estate market, when the interaction between Crisis and LongLease (Crisis*LongLease) is added, MSCI*LongLease is dropped in the regression model. The coefficient of Crisis*LongLease is significant and positive and the coefficient of LongLease becomes insignificant, this indicates that long lease funds outperformed balanced funds during the crisis periods. The reason that long lease funds out-performed balanced funds on average is due to the outperformance of long lease funds during the crisis periods. Both long lease funds and balanced funds have liability hedging features as their performances are negatively associated with gilt yield changes. However, long lease funds have achieved better returns, especially during crisis periods. R-squared of all the models is above $84 \%$, which indicates that our model can explain most of the variations of fund returns. We checked the Variance Inflation Factor (VIF). Since there is no variable with VIF more than 5, we do not have a multicollinearity problem.

$<$ Insert Table II about here>

\subsection{Robustness Checks}

This section contains a number of robustness checks of the regression estimations. First, following the methodology of Delfim and Hoesli (2016), the regression analysis was repeated using random effect panel regressions, which allows us to control for unobserved fund characteristics. Fixed effect panel regression was not appropriate for this study because LongLease is a time-invariant variable and the main variable of our interest, using the fixed effect model would eliminate LongLease. Table III shows the estimation results of random effect panel regressions. The results are consistent with the pooled OLS estimations in Table II. Second, robust M-estimation is a regression method that is 
used when the distribution of residual is not normal (Susanti and Pratiwi, 2014) ${ }^{9}$. Table IV shows the estimation results with robust $\mathrm{M}$-estimation. The results are consistent with the least square estimation in Table II. Third, as discussed in Sections 4 and 5.2, long lease property funds and balanced property funds may also differ in holding different types of commercial real estate. To control for the heterogeneity of asset holdings and in particular sector exposures, we use WMR instead of $\mathrm{MSCl}$ to capture the underlying market movement, which should reduce the impact of sector differences in driving performance differences. Table $V$ shows the estimation results with WMR. The results are consistent with the estimation using $\mathrm{MSCl}$ shown in Table II. Even considering the possible differences in asset holding between two types of funds, long lease funds still outperformed balanced funds, and this is mainly due to the outperformance during the crisis periods.

$<$ Insert Table III about here>

$<$ Insert Table IV about here>

$<$ Insert Table $\mathrm{V}$ about here $>$

\section{Conclusions}

The purpose of this paper is to explore the growth of long lease real estate funds and to understand the return and risk characteristics of long lease real estate. Previous research on long lease real estate has been based on simulations. This paper analyses the actual performance and risk of these funds.

Long lease real estate funds are now a substantial part of the UK fund universe with a value of over f15bn. Their growth has been associated with a general de-risking of UK pension schemes over the last two decades, a supportive regulatory position and strong relative performance.

Long lease real estate funds have out-performed balanced property funds and gilt total returns on average over the 2004-20 period. Their volatility has been far closer to gilts than the wider property market. Consequently, they have out-performed balanced property funds (and direct property) on a risk-adjusted return basis. Long lease real estate funds have far higher exposure to "other" property and less exposure to retail and offices than balanced funds but this difference in sector allocation does not explain their outperformance. Adjusting for sector exposure, long lease funds have still outperformed, particularly during the GFC, aftermath of the EU referendum and Covid-19 periods. It shows the defensive nature of long lease real estate during economic uncertainty and economic downturn periods.

Long lease funds typically have objectives to out-perform gilts or to provide a real return in contrast to balanced property funds that have performance objectives focussed on the peer group e.g. the balanced fund index or a more general property index benchmark. Comparing long lease funds with balanced funds (funds with general property market exposure), both types of funds are negatively associated with gilt yield changes but only weakly. Perhaps surprisingly, there is not a significant

\footnotetext{
${ }^{9}$ Robust regression estimator is more reliable and efficient than least square estimator when the distribution of residual is not normal.
} 
difference in the short-term sensitivity to gilt yield changes between balanced property funds and long lease funds. Long lease funds are less sensitive to the real estate market than balanced funds, especially during crisis periods. These defensive properties, the alignment of objectives and the negative correlation with gilt yields support the Pensions Regulator position that long lease real estate is suitable for long-term matching purposes. However, we find no evidence that long lease funds are a more reliable short-term liability-matching asset than balanced property funds.

For pension fund trustees, managers and consultants a key question is how to de-risk their portfolio in an environment of very low interest rates and bond yields. This paper highlights that long lease real estate funds have provided attractive risk-adjusted returns. Long lease real estate funds are treated as a matching asset by The Pensions Regulator and have objectives that appear well aligned with longer term liability matching. However, we find no evidence that they have a significantly stronger correlation with bond yields than balanced real estate funds and so some caution regarding their liability matching characteristics in the short term is appropriate.

For real estate fund managers, this paper highlights the strong performance of these funds and given the factors that have driven the growth of these funds, the market appetite is likely to remain strong.

For real estate investors and developers, the strong demand for long lease real estate, reflecting the factors outlined in this paper, is likely to persist creating an opportunity for those that can deliver assets to help satisfy that demand. Similarly, for occupiers, particularly those with assets and covenants that provide a strong degree of income security, highlights the opportunity to sell assets to long lease real estate funds and investors.

Given limited data availability and information about long lease funds, we are unable to test the duration of long lease real estate comprehensively or look at liability matching characteristics over longer time horizons. Future research, with a more extended time series of long lease funds data and the actual lease and property level information could examine in more depth how lease structure affects the performance, risk, and liability hedging characteristics of real estate assets over different investment horizons. In addition, future research could also explore more directly with real estate fund managers the extent to which liability matching characteristics are taken into account in asset selection and how this is reflected in fund performance and the relationship of fund performance with bond yields. 


\section{References}

Alcock, J., Baum, A., Colley, N. and Steiner, E., 2013. The role of financial leverage in the performance of private equity real estate funds. The Journal of Private Equity, 17(1), pp.80-91.

Andrew, M. and Glenn, M., 2003. Public and private real estate in a mixed-asset portfolio. Journal of Real Estate Portfolio Management, 9(3), pp.193-203.

Arnold, T.R., Ling, D.C. and Naranjo, A., 2019. Private equity real estate funds: returns, risk exposures, and persistence. The Journal of Portfolio Management, 45(7), pp.24-42.

Bollinger, M.A. and Pagliari, J.L., 2019. Another Look at Private Real Estate Returns by Strategy. The Journal of Portfolio Management, 45(7), pp.95-112.

Carlo, A., Eichholtz, P. and Kok, N., 2021. Three Decades of Global Institutional Investment in Commercial Real Estate. The Journal of Portfolio Management, 47(10), pp.25-40.

Chaney, A. and Hoesli, M., 2010. The interest rate sensitivity of real estate. Journal of Property Research, 27(1), pp.61-85.

Chun, G.H., Ciochetti, B.A. and Shilling, J.D., 2000. Pension-Plan Real Estate Investment in an AssetLiability Framework. Real Estate Economics, 28(3), pp.467-491.

Chun, G.H., Sa-Aadu, J. and Shilling, J.D., 2004. The role of real estate in an institutional investor's portfolio revisited. The Journal of Real Estate Finance and Economics, 29(3), pp.295-320.

Ciochetti, B., Sa-Aadu, J. and Shilling, J., 1999. Determinants of real estate asset allocations in private and public pension plans. The Journal of Real Estate Finance and Economics, 19(3), pp.193-210.

Craft, T., 2001. The role of private and public real estate in pension plan portfolio allocation choices. Journal of Real Estate Portfolio Management, 7(1), pp.17-23.

Defau, L. and De Moor, L., 2021. The investment behaviour of pension funds in alternative assets: Interest rates and portfolio diversification. International Journal of Finance \& Economics, 26(1), pp.1424-1434.

Delfim, J.C. and Hoesli, M., 2016. Risk factors of European non-listed real estate fund returns. Journal of Property Research, 33(3), pp.190-213.

Delfim, J.C. and Hoesli, M., 2019. Real estate in mixed-asset portfolios for various investment horizons. The Journal of Portfolio Management, 45(7), pp.141-158.

Farrelly, K. and Stevenson, S., 2016. Performance drivers of private real estate funds. Journal of Property Research, 33(3), pp.214-235.

Fisher, L.M. and Hartzell, D.J., 2016. Class differences in real estate private equity fund performance. The Journal of Real Estate Finance and Economics, 52(4), pp.327-346.

Fuerst, F., Mansley, N. and Wang, Z., 2021. Do Specialist Funds Outperform? Evidence from European Non-Listed Real Estate Funds. Research in International Business and Finance. 58, p.101434.

Fuerst, F. and Matysiak, G., 2013. Analysing the performance of nonlisted real estate funds: a panel data analysis. Applied Economics, 45(14), pp.1777-1788.

Hartzell, D.J., Shulman, D.G., Langetieg, T.C. and Leibowitz, M.L., 1988. A look at real estate duration. Journal of Portfolio Management, 15(1), p.16. 
Hoesli, M. and Lekander, J., 2005. Suggested vs. Actual Institutional Allocation to Real Estate in Europe: A Matter of Size. FAME Research Paper, (149), International Center for Financial Asset Management and Engineering.

Hoesli, M., Lekander, J. and Witkiewicz, W., 2004. International evidence on real estate as a portfolio diversifier. Journal of Real Estate Research, 26(2), pp.161-206.

Kallberg, J.G., Liu, C.H. and Greig, D.W., 1996. The role of real estate in the portfolio allocation process. Real Estate Economics, 24(3), pp.359-377.

Kallberg, J.G., Liu, C.H. and Greig, D.W., 1996. The role of real estate in the portfolio allocation process. Real Estate Economics, 24(3), pp.359-377.

Institutional Real Estate, INC., 2018, 2018 Institutional Investor Real Estate Trends, available at https://irei.com/wp-content/uploads/woocommerce uploads/2018/04/2018 IRE-Trends-

Survey.pdf (accessed 20 October 2021).

IPF, 2007, Asset Allocation in the Modern World, available at

https://www.ipf.org.uk/resourceLibrary/asset-allocation-in-the-modern-world--july-2007-.html (accessed 20 October 2021)

IPF, 2020, Long-Term Value Methodologies in Commercial Real Estate Lending Analysis, available at https://www.ipf.org.uk/resourceLibrary/ipf-long-term-value-methodologies-in-commercial-realestate-lending--july-2020--full-report-.html (accessed 20 April 2021)

Lee, S. and Stevenson, S., 2006. Real estate in the mixed-asset portfolio: the question of consistency. Journal of Property Investment \& Finance, 24(1), pp. 123-135.

Lekander, J.R., 2015. Real estate portfolio construction for a multi-asset portfolio. Journal of Property Investment \& Finance, 33(6), pp. 548-573.

Mansley, N., Tse, T.C.M. and Wang, Z., 2020. Risk classification of Asian real estate funds and their performance. Pacific-Basin Finance Journal, 63, p.101400.

MSCl, 2019, UK Lease Events Review, available at https://www.msci.com/www/research-paper/uklease-events-review-november/01646887740 (accessed 20 April 2021)

Pagliari Jr, J.L., 2017. Another Take on Real Estate's Role in Mixed-Asset Portfolio Allocations. Real Estate Economics, 45(1), pp.75-132.

Pagliari Jr, J.L., 2020. Real Estate Returns by Strategy: Have Value-Added and Opportunistic Funds Pulled Their Weight?. Real Estate Economics, 48(1), pp.89-134.

Pension Protection Fund, 2020, The Purple Book 2020, available at https://www.ppf.co.uk/sites/default/files/2020-12/PPF Purple Book 20.pdf (accessed 20 April 2021)

Rehring, C., 2012. Real Estate in a Mixed-Asset Portfolio: The Role of the Investment Horizon. Real Estate Economics, 40(1), pp.65-95.

Schroders, 2019, Institutional Investor Study 2019, available at https://www.schroders.com/en/sg/institutional-investor/insights/institutional-investor-study/ (accessed 20 October 2021) 
Susanti, Y. and Pratiwi, H., 2014. M estimation, S estimation, and MM estimation in robust regression. International Journal of Pure and Applied Mathematics, 91(3), pp.349-360.

The Pension Regulator, 2019, DB investment, available at https://www.thepensionsregulator.gov.uk/en/document-library/regulatory-guidance/dbinvestment/matching-db-assets. (accessed 20 April 2021)

Tomperi, I., 2010. Performance of private equity real estate funds. Journal of European Real Estate Research, G(2), pp.96-116

UBS, 2015. A long term perspective on pension fund investment - Pension Fund Indicators 
Appendix: Variable definition

\begin{tabular}{|c|c|}
\hline Variable & Definition \\
\hline \multicolumn{2}{|c|}{ Depend variable } \\
\hline Total Return & Annual total return \\
\hline \multicolumn{2}{|c|}{ Independent variables } \\
\hline $\mathrm{MSCl}$ & $\begin{array}{l}\text { Direct real estate return: total return of } \mathrm{MSCl} \text { all } \\
\text { property }\end{array}$ \\
\hline NAV & Net asset value in $\mathrm{fm}$ in previous year \\
\hline LongLease & $\begin{array}{l}\text { Dummy variable that takes a value of } 1 \text { if the } \\
\text { fund is a long lease fund, otherwise } 0 .\end{array}$ \\
\hline Yield10Y & $\begin{array}{l}\text { Annual change of } 10 \text {-year government bond } \\
\text { yield }\end{array}$ \\
\hline GDP_growth & Annual GDP growth rate \\
\hline LGDP_growth & Lagged annual GDP growth rate \\
\hline Crisis & $\begin{array}{l}\text { Dummy variable that takes a value of } 1 \text { if the } \\
\text { year is } 2008,2009,2016 \text { or } 2020 \text {, otherwise } 0 .\end{array}$ \\
\hline
\end{tabular}


Table I: Long lease property and balanced fund characteristics

\begin{tabular}{|l|c|c|c|c|}
\hline & $\begin{array}{c}\text { Long Lease } \\
\text { Property } \\
\text { Funds }\end{array}$ & $\begin{array}{c}\text { Balanced } \\
\text { Property } \\
\text { Funds }\end{array}$ & $\begin{array}{c}\text { MSCl } \\
\text { Monthly } \\
\text { Property } \\
\text { Index }\end{array}$ & $\begin{array}{c}\text { 10-year Gilt } \\
\text { Total Return } \\
\text { Index }\end{array}$ \\
\hline NAV fbn Sept 2020 & 14.8 & 30.0 & 37.0 & \\
\hline $\begin{array}{l}\text { Gearing Sept 2020 } \\
\text { ((Cash-Debt)/NAV) }\end{array}$ & $-1.9 \%$ & $-6.9 \%$ & 0 & \\
\hline Exposure to "other" (\%) & 45.5 & 10.6 & 5.4 & \\
\hline $\begin{array}{l}\text { Annualised Return Sep 2004- } \\
\text { Sep 2020 }\end{array}$ & $6.6 \%$ & $4.8 \%$ & $6.1 \%$ & $6.1 \%$ \\
\hline Mean Qtly Return & $1.6 \%$ & $1.2 \%$ & $1.6 \%$ & $1.6 \%$ \\
\hline Mean Annual Return & $6.9 \%$ & $5.5 \%$ & $6.9 \%$ & $6.2 \%$ \\
\hline Max “Drawdown" & $-19.7 \%$ & $-39.0 \%$ & $-36.7 \%$ & $-7.1 \%$ \\
\hline $\begin{array}{l}\text { SD Quarterly returns } \\
\text { (annualised) }\end{array}$ & $4.1 \%$ & $7.0 \%$ & $7.1 \%$ & $6.8 \%$ \\
\hline SD-Annual returns & $7.1 \%$ & $12.3 \%$ & $12.4 \%$ & $5.2 \%$ \\
\hline Sharpe Ratio-Annual Return & 0.75 & 0.33 & 0.43 & 0.90 \\
\hline Minimum Quarterly Return & $-5.9 \%$ & $-13.4 \%$ & $-13.5 \%$ & $-7.1 \%$ \\
\hline Skewness & -1.4 & -1.8 & -1.7 & -0.1 \\
\hline Kurtosis & 4.7 & 5.0 & 5.0 & 0.3 \\
\hline
\end{tabular}

Source: $\mathrm{MSCl}$, author's calculations.

Notes: Annual returns are for Sept-Sept. Max drawdown refers to the maximum decline in the total return index. The MPI does not allow for fund expense and management costs. For the calculation of Sharpe ratio, the risk-free rate is the yield of 3-month government bond divided by 4 . 
Table II: Regression results

\begin{tabular}{|c|c|c|c|}
\hline & $\begin{array}{c}\text { (1) } \\
\text { Total Return }\end{array}$ & $\begin{array}{c}\text { (2) } \\
\text { Total Return }\end{array}$ & $\begin{array}{c}\text { (3) } \\
\text { Total Return }\end{array}$ \\
\hline $\mathrm{MSCl}$ & $\begin{array}{l}1.000^{* * *} \\
(28.41)\end{array}$ & $\begin{array}{l}1.072^{* * *} \\
(35.28)\end{array}$ & $\begin{array}{l}1.004^{* * *} \\
(25.03)\end{array}$ \\
\hline NAV & $\begin{array}{l}0.000 \\
(0.97)\end{array}$ & $\begin{array}{l}0.000 \\
(1.32)\end{array}$ & $\begin{array}{l}0.000 \\
(1.11)\end{array}$ \\
\hline LongLease & $\begin{array}{c}1.870^{* * *} \\
(2.63)\end{array}$ & $\begin{array}{c}5.354^{* * *} \\
(6.12)\end{array}$ & $\begin{array}{l}-0.386 \\
(-0.59)\end{array}$ \\
\hline Yield10Y & $\begin{array}{c}-0.008^{* *} \\
(-2.56)\end{array}$ & $\begin{array}{c}-0.008^{* *} \\
(-2.32)\end{array}$ & $\begin{array}{l}-0.009^{*} \\
(-1.73)\end{array}$ \\
\hline GDP_growth & $\begin{array}{l}-0.081 \\
(-0.93)\end{array}$ & $\begin{array}{l}-0.045 \\
(-0.56)\end{array}$ & $\begin{array}{l}-0.146 \\
(-1.15)\end{array}$ \\
\hline LGDP_growth & $\begin{array}{l}0.411^{* *} \\
(2.35)\end{array}$ & $\begin{array}{c}0.370^{* *} \\
(2.24)\end{array}$ & $\begin{array}{l}0.414^{* *} \\
(2.45)\end{array}$ \\
\hline MSCI*LongLease & & $\begin{array}{c}-0.581^{* * *} \\
(-6.50)\end{array}$ & \\
\hline Yield10Y*LongLease & & $\begin{array}{l}0.009 \\
(1.38)\end{array}$ & $\begin{array}{l}0.019 \\
(1.53)\end{array}$ \\
\hline Crisis & & & $\begin{array}{l}-1.319 \\
(-1.62)\end{array}$ \\
\hline Crisis*LongLease & & & $\begin{array}{c}8.967^{* * *} \\
(4.16)\end{array}$ \\
\hline Constant & $\begin{array}{c}-2.574^{* * *} \\
(-2.93) \\
\end{array}$ & $\begin{array}{c}-2.977^{* * *} \\
(-3.67) \\
\end{array}$ & $\begin{array}{c}-2.092^{* *} \\
(-2.57) \\
\end{array}$ \\
\hline$N$ & 507 & 507 & 507 \\
\hline$R^{2}$ & 0.847 & 0.881 & 0.860 \\
\hline
\end{tabular}


Table III: Random effect estimation

\begin{tabular}{|c|c|c|c|}
\hline & $\begin{array}{c}\text { (1) } \\
\text { Total Return }\end{array}$ & $\begin{array}{c}\text { (2) } \\
\text { Total Return }\end{array}$ & $\begin{array}{c}\text { (3) } \\
\text { Total Return }\end{array}$ \\
\hline $\mathrm{MSCl}$ & $\begin{array}{c}0.991^{* * *} \\
(18.34)\end{array}$ & $\begin{array}{c}1.059 * * * \\
(24.48)\end{array}$ & $\begin{array}{c}0.989 * * * \\
(17.09)\end{array}$ \\
\hline NAV & $\begin{array}{l}0.000 \\
(1.21)\end{array}$ & $\begin{array}{c}0.000 * * \\
(2.03)\end{array}$ & $\begin{array}{l}0.000 \\
(1.55)\end{array}$ \\
\hline LongLease & $\begin{array}{c}2.032^{* * *} \\
(3.76)\end{array}$ & $\begin{array}{c}5.499 * * * \\
(5.50)\end{array}$ & $\begin{array}{l}-0.165 \\
(-0.26)\end{array}$ \\
\hline Yield10Y & $\begin{array}{c}-0.008^{* * *} \\
(-2.98)\end{array}$ & $\begin{array}{c}-0.007^{* *} \\
(-2.41)\end{array}$ & $\begin{array}{c}-0.009 * * \\
(-2.13)\end{array}$ \\
\hline GDP_growth & $\begin{array}{l}-0.043 \\
(-0.65)\end{array}$ & $\begin{array}{l}0.006 \\
(0.09)\end{array}$ & $\begin{array}{l}-0.090 \\
(-0.95)\end{array}$ \\
\hline LGDP_growth & $\begin{array}{c}0.406 * * * \\
(3.03)\end{array}$ & $\begin{array}{c}0.355^{* * *} \\
(2.63)\end{array}$ & $\begin{array}{c}0.400 * * * \\
(2.85)\end{array}$ \\
\hline MSCI*LongLease & & $\begin{array}{c}-0.573^{* * *} \\
(-4.75)\end{array}$ & \\
\hline Yield10Y*LongLease & & $\begin{array}{l}0.008 \\
(1.34)\end{array}$ & $\begin{array}{l}0.018 \\
(1.60)\end{array}$ \\
\hline Crisis & & & $\begin{array}{l}-1.410 \\
(-1.63)\end{array}$ \\
\hline Crisis*LongLease & & & $\begin{array}{c}8.808 * * * \\
(3.59)\end{array}$ \\
\hline Constant & $\begin{array}{c}-2.914^{* * *} \\
(-3.35)\end{array}$ & $\begin{array}{c}-3.374 * * * \\
(-3.99)\end{array}$ & $\begin{array}{c}-2.442 * * * \\
(-2.70)\end{array}$ \\
\hline$N$ & 507 & 507 & 507 \\
\hline$R^{2}$ & 0.845 & 0.879 & 0.857 \\
\hline
\end{tabular}


Table IV: Robust M-estimation

\begin{tabular}{|c|c|c|c|}
\hline & $\begin{array}{c}\text { (1) } \\
\text { Total Return }\end{array}$ & $\begin{array}{c}\text { (2) } \\
\text { Total Return }\end{array}$ & $\begin{array}{c}\text { (3) } \\
\text { Total Return }\end{array}$ \\
\hline \multirow[t]{2}{*}{$\mathrm{MSCl}$} & $0.971^{* * *}$ & $0.977^{* * *}$ & $0.978 * * *$ \\
\hline & (59.02) & $(64.40)$ & (38.15) \\
\hline \multirow[t]{2}{*}{ NAV } & 0.000 & -0.000 & -0.000 \\
\hline & $(0.10)$ & $(-0.34)$ & $(-0.08)$ \\
\hline \multirow[t]{2}{*}{ LongLease } & $1.401^{* * *}$ & $5.577 * * *$ & $0.930 * *$ \\
\hline & (3.96) & $(14.66)$ & $(2.24)$ \\
\hline \multirow[t]{2}{*}{ Yield10Y } & $-0.008 * *$ & $-0.007 * *$ & -0.003 \\
\hline & $(-2.46)$ & $(-2.00)$ & $(-0.62)$ \\
\hline \multirow[t]{2}{*}{ GDP_growth } & -0.048 & 0.046 & -0.096 \\
\hline & $(-0.63)$ & $(0.67)$ & $(-1.06)$ \\
\hline \multirow[t]{2}{*}{ LGDP_growth } & $0.338 * * *$ & $0.395 * * *$ & $0.318 * * *$ \\
\hline & (3.84) & $(5.03)$ & $(3.50)$ \\
\hline \multirow[t]{2}{*}{ MSCI*LongLease } & & $-0.673^{* * *}$ & \\
\hline & & $(-21.22)$ & \\
\hline \multirow[t]{2}{*}{ Yield10Y*LongLease } & & $0.015^{* *}$ & -0.012 \\
\hline & & $(2.18)$ & $(-1.42)$ \\
\hline \multirow[t]{2}{*}{ Crisis } & & & 0.209 \\
\hline & & & $(0.37)$ \\
\hline \multirow[t]{2}{*}{ Crisis*LongLease } & & & 1.295 \\
\hline & & & $(1.42)$ \\
\hline \multirow[t]{2}{*}{ Constant } & $-1.554 * * *$ & $-2.009 * * *$ & $-1.344 * * *$ \\
\hline & $(-4.12)$ & $(-5.95)$ & $(-3.23)$ \\
\hline$N$ & 507 & 507 & 507 \\
\hline$R^{2}$ & 0.928 & 0.937 & 0.928 \\
\hline
\end{tabular}


Table V: Regression with WMR

\begin{tabular}{|c|c|c|c|}
\hline & $\begin{array}{c}\text { (1) } \\
\text { Total Return }\end{array}$ & $\begin{array}{c}\text { (2) } \\
\text { Total Return }\end{array}$ & $\begin{array}{c}\text { (3) } \\
\text { Total Return }\end{array}$ \\
\hline $\mathrm{MSCl}$ & $\begin{array}{c}0.922 * * * \\
(24.73)\end{array}$ & $\begin{array}{c}0.996 * * * \\
(30.50)\end{array}$ & $\begin{array}{c}0.711^{* * *} \\
(11.35)\end{array}$ \\
\hline NAV & $\begin{array}{l}-0.000 \\
(-0.78)\end{array}$ & $\begin{array}{l}-0.000 \\
(-0.19)\end{array}$ & $\begin{array}{l}-0.000 \\
(-0.01)\end{array}$ \\
\hline LongLease & $\begin{array}{c}3.204^{* * *} \\
(4.09)\end{array}$ & $\begin{array}{c}6.277^{* * *} \\
(7.49)\end{array}$ & $\begin{array}{c}1.345^{*} \\
(1.79)\end{array}$ \\
\hline Yield10Y & $\begin{array}{l}-0.003 \\
(-0.94)\end{array}$ & $\begin{array}{l}-0.005 \\
(-1.16)\end{array}$ & $\begin{array}{c}-0.029 * * * \\
(-3.84)\end{array}$ \\
\hline GDP_growth & $\begin{array}{c}0.520 * * * \\
(3.22)\end{array}$ & $\begin{array}{c}0.599 * * * \\
(3.83)\end{array}$ & $\begin{array}{c}0.918^{* * *} \\
(4.40)\end{array}$ \\
\hline LGDP_growth & $\begin{array}{l}-0.168 \\
(-0.69)\end{array}$ & $\begin{array}{l}-0.198 \\
(-0.85)\end{array}$ & $\begin{array}{l}-0.300 \\
(-1.32)\end{array}$ \\
\hline MSCI*LongLease & & $\begin{array}{c}-0.678^{* * *} \\
(-7.64)\end{array}$ & \\
\hline Yield10Y*LongLease & & $\begin{array}{c}0.011^{*} \\
(1.79)\end{array}$ & $\begin{array}{l}0.012 \\
(0.78)\end{array}$ \\
\hline Crisis & & & $\begin{array}{c}-7.317^{* * *} \\
(-5.03)\end{array}$ \\
\hline Crisis*LongLease & & & $\begin{array}{c}6.502^{* *} \\
(2.58)\end{array}$ \\
\hline Constant & $\begin{array}{l}-1.139 \\
(-1.04)\end{array}$ & $\begin{array}{c}-1.804^{*} \\
(-1.73)\end{array}$ & $\begin{array}{l}0.892 \\
(0.90)\end{array}$ \\
\hline$N$ & 507 & 507 & 507 \\
\hline$R^{2}$ & 0.766 & 0.803 & 0.794 \\
\hline
\end{tabular}

